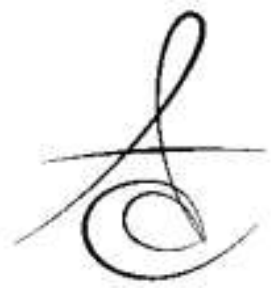

\title{
EFFECTS OF DESENSITIZERS ON RESIN CEMENT BONDING
}

\section{DENTİN HASSASİYET GİDERİCİ AJANLARIN REZİN SİMANIN BAĞLANMASINA} ETKİSI

\author{
Dr. Öğr. Üyesi Esra KUL* \\ Dr. Öğr. Üyesi Merve İŞCAN YAPAR ${ }^{* *}$
}

Prof. Dr. Funda BAYINDIR*

Dr. Öğr. Üyesi Ruhi YEŞİLDAL ${ }^{* * *}$
Makale Kodu/Article code: 4107

Makale Gönderilme tarihi; 27.05 .2019

Kabul Tarihi: 27.11.2019

DOI : $10.17567 /$ ataunidfd.651598
Esra Kul: ORCID ID: 0000-0003-4750-8955

Funda Bayındır: ORCID ID: 0000-0001-5699-2879

Merve İşcan Yapar: ORCID ID:0000-0002-9712-0978

Ruhi Yeșildal: ORCID ID:0000-0001-7677-1600

\section{ABSTRACT}

Aim: The purpose of this in vitro study was to determine how pretreatment with desensitizers affects micro-tensile bond strength between dentin and self-etch resin cement (SEC).

Material and Methods: The occlusal surfaces of extracted teeth were abraded with a diamond bur to the dentin layer and divided into 5 equal groups $(n=20)$; G1- control (no desensitizer, only Clearfil aesthetic resin cement (CEC); G2-Gluma and CEC; G3-Bi-fluorid 12 and CEC; G4-FGM desensitizer and CEC; G5- D/Sense Crystal and CEC. Resin cement layers were added to a depth of $8 \mathrm{~mm}$ in the control group, and desensitizer was applied to the surfaces before resin cement application in the other experimental groups. A specimen from each group was examined with scanning electron microscopy. The specimens were sectioned to be $1 \mathrm{~mm}^{2}$ perpendicular to the adhesive layer, and the microtensile test was applied. According to the results of the post hoc Tamhane test, there was a significant difference. $(p<0.05)$.

Results: Only the Gluma desensitizer had a significantly lower bond strength value when compared with the other desensitizers and the control group.

Conclusions: While dentin with oxalate, fluoride, and strontium chloride-potassium nitrate contamination did not affect the bonding strength of SEC, dentin contamination with glutaraldehyde/HEMA had a negative effect.

Keywords. Desensitizer; self-etch resin cement; microtensile bond strength.

\section{öz}

Amaç: $\mathrm{Bu}$ in vitro çalışmanın amacı, dentine hassasiyet giderici ajan uygulamasının, self-etch rezin simanın (SEC) mikrogerilim bağlanma dayanımını nasıl etkilediğini araştırmaktır.

Gereç ve Yöntem: Çekilmiş dişlerin oklüzal yüzleri elmas frez ile dentin tabakasına kadar aşındırıldı ve 5 eşit gruba ayrıldı $(n=$ 20); G1- kontrol (hassasiyet giderici ajan kullanılmadı, sadece Clearfil estetik rezin siman (CEC); G2-Gluma ve CEC; G3-Bi-fluorid 12 ve CEC; G4-FGM ve CEC; G5-D/Sense Crystal ve CEC. Kontrol grubunda, dentin üzerine $8 \mathrm{~mm}$ yüksekliğinde rezin siman tabakası eklendi ve diğer deney gruplarına rezin simandan önce dentin hassasiyet giderici ajanlar uygulandı. Her gruptan bir örnek taramalı elektron mikroskobu ile incelendi. Örnekler dentin-siman bağlantısına dik olarak $1 \mathrm{~mm}^{2}$ olacak şekilde kesildi ve mikrogerilim bağlanma dayanımı ölçüldü. Post-hoc Tamhane testinin sonuçlarına göre anlamlı bir fark vardı $(p<0.05)$.

Bulgular: Dentin hassasiyet giderici ajanlar arasında sadece Gluma, diğer gruplar ve kontrol grubu ile karşılaştıııldığında anlamlı şekilde daha düşük bir bağlanma dayanımına sahipti.

Sonuç: Dentin üzerine oksalat, florür ve stronsiyum klorür-potasyum nitrat uygulaması, SEC ile arasındaki bağlanma dayanımını etkilemese de, glutaraldehit/HEMA uygulaması olumsuz etkilemiştir.

Anahtar kelimeler: Hassasiyet giderici ajan; Self-etch rezin siman; Mikrogerilim bağlanma testi

\section{* Department of Prosthodontics, Faculty of Dentistry at Atatürk University, Erzurum, TURKEY. \\ ** Department of Restorative dentistry, Faculty of Dentistry at Atatürk University, Erzurum, TURKEY. \\ *** Department of Mechanical Engineering, Faculty of Engineering at Atatürk University, Erzurum, TURKEY}

Kaynakça Bilgisi: Kul E, Bayındır F, İşcan Yapar M, Yeşildal R. Dentin Hassasiyet Giderici Ajanların Rezin Simanın Bağlanmasına Etkisi. Atatürk Üniv Diş Hek Fak Derg 2020; 30: 107-112.

Citation Information: Kul E, Bayindir F, Iscan Yapar M, Yesildal R. Effects of Desensitizers on Resin Cement Bonding. J Dent Fac Atatürk Uni 2020 ; 30 : 107-112. 


\section{INTRODUCTION}

Dentin sensitivity after tooth preparation is a concern in clinical practice ${ }^{1}$ and can be controlled by reducing the permeability of the dentin tubules. ${ }^{2}$ Products available for such treatment include those incorporating fluoride, ${ }^{2-4}$ hydroxyethyl methacrylate (HEMA)/glutaraldehyde, ${ }^{5-8}$ oxalate, ${ }^{9-12}$ potassium nitrate, and calcium phosphate, ${ }^{13}$ of which HEMA/ glutaraldehyde is the most widely used. $^{6}$ Glutaraldehyde works by coagulating proteins in the dentin tubules, and HEMA by forming resinous tags that occlude the dentinal tubules. ${ }^{14}$ Desensitizing agents (DAs) and their effects on the bond between dentin and resin cement have been studied, with some studies reporting that the administration of DAs prior to the cementation of restorations reduces crown retention ${ }^{10,15,16}$; however, another study reported no adverse effects ${ }^{14}$ and even increased retention.

The application of calcium oxalate to dentin ${ }^{17}$ blocks the dentinal tubules, ${ }^{18}$ leading to immediate nerve fiber depolarization by potassium ions and then tubular occlusion from the gradual formation of calcium oxalate crystals. ${ }^{19}$ The action of acidic potassium oxalate solutions depends on the chemical interaction of the calcium ions and the dentin fluid caused by the calcium oxalate crystals occluding and/or obstructing the tubules. ${ }^{20}$ The same applies to fluoride, which produces calcium fluoride crystals in the tubules and reduces the conductivity of dentin. ${ }^{18}$ $\mathrm{D} /$ Sense Crystal is a cavity liner and 1-step, dualaction gel desensitizer material that reacts with dentin and precipitates calcium oxalate microcrystals and potassium nitrate; these crystals go deep into the tubules, sealing the dentinal surface with an uninterrupted, acid-resistant complex.

Desensibilize (FGM Produtos Odontológicos) is a neutral viscous solution that combines 2 mechanisms for desensitization: occlusion of the dentinal tubules by strontium chloride and a neural action by potassium nitrate. The authors are unaware of studies that have investigated whether products of this type reduce the permeability of dentin and therefore affect the bonding of resin cement.

The general purpose of applying agents to block the dentin tubules is to reduce the permeability of the dentin. ${ }^{21,22}$ However, the effects of desensitizer treatment on bonding are not fully known. An oxalatecontaining DA has been reported to weaken resin infiltration due to precipitation onto the dentin layer as calcium oxalate crystals. ${ }^{20,23}$ However, it has been reported ${ }^{24,11}$ that potassium oxalate crystals that form a more stable and more homogeneous hybrid layer do not reduce the bonding between resin and dentin.

Whether the application of desensitizers containing different types of agents on the dentin surface affects the bonding between dentin and SEC is unclear. The null hypothesis of the study was that no variation in bonding would be found among the adhesive systems, regardless of the desensitizing agent applied. When using self-etch resin cement for cementation, it is preferable to use oxalate, fluoride, and strontium chloride-potassium nitrate when it is necessary to use desensitizing agents.

\section{MATERIAL AND METHODS}

The products and the methods used in this study are presented in Table 1. In the control group, the dentin surface was untreated. The Scientific Ethics Committee of Atatürk University approved the study protocol with the $8 / 2018$ protocol, and a total of 30 extracted third molar teeth were collected. The teeth were ground with a diamond bur (KG Sorensen) under water so that the dentin surfaces were exposed. The occlusal surfaces of the teeth were ground with abrasive paper under water for 60 seconds, and the dentin surface was examined with an optical microscope (Olympus SZX7) to ensure that no enamel remained. The specimens were divided into 5 groups and stored in distilled water. The DA was applied according to the manufacturer's instructions (Table 1). Resin cement was applied (Clearfil aesthetic cement, Kuraray) on the dentin surfaces with a layering technique (total of $8 \mathrm{~mm}$ of resin cement), and the bonded resin cement was polymerized. The specimens were cut into microbars $(10 \times 1 \times 1 \mathrm{~mm})$ with a precision sectioning saw (Isomet 1000, Buehler, Evanston IL, USA), and 20 intact microbars were included in each group for microtensile bond strength (Mtbs) testing. Each specimen was centered using cyanoacrylate adhesive (Akfix 705, Turkey) that the resin-dentin interface was between the jaws of the unit. A crosshead speed of $0.5 \mathrm{~mm} / \mathrm{min}$ was applied ( $\mathrm{T}$ $610-10 \mathrm{~K}$, Bisco dental), and the load was recorded at specimen fracture in $\mathrm{N} / \mathrm{mm}^{2}$. The homogeneity of the variances was evaluated by the Levene test, and the difference between the groups was determined using one-way ANOVA $(a=.05)$. The post hoc Tamhane statistical analysis was used to determine the different 
groups when the $p$ value was found to be significant, since the variances were not homogenous.

In this in vitro study, the Mtbs between the dentin surfaces on which various dentin desensitizing agents were applied and the self-etch, dual-cure resin cement were investigated.

Table 1. Composition of desensitizers and resin cement

\begin{tabular}{|c|c|c|c|}
\hline Desensitizer & Contents & Application protocol & \\
\hline $\begin{array}{c}\text { Gluma } \\
\text { Desensitizer }\end{array}$ & $\begin{array}{l}\text { HEMA (25-50\%), } \\
\text { glutaraldehyde (5- } \\
10 \%), \text { distilled water }\end{array}$ & $\begin{array}{c}\text { After application on } \\
\text { dried dentin, wait 30- } \\
60 \text { seconds and gently } \\
\text { dry with air. }\end{array}$ & $\begin{array}{l}\text { Heraeus } \\
\text { Germany }\end{array}$ \\
\hline $\begin{array}{l}\text { D/Sense } \\
\text { Crystal }\end{array}$ & $\begin{array}{l}\text { Potassium binoxalate } \\
2,5 \% \text {, Nitric acid 2,5\% }\end{array}$ & $\begin{array}{c}\text { Apply on tooth } \\
\text { surface, allow } \\
\text { permeation for } 20 \mathrm{~s} \\
\text { dry for } 30 \mathrm{~s} \text {, wait for } \\
2 \mathrm{~m} \text { (typically less } \\
\text { than } 3 \text { microns thick). }\end{array}$ & Centrix Inc. \\
\hline $\begin{array}{c}\text { Bi-fluoride } 12 \\
\text { Suspension }\end{array}$ & $\begin{array}{l}\text { Sodium fluoride } 60 \\
\mathrm{mg} / \mathrm{g}(6.0 \% \mathrm{w} / \mathrm{w}), \\
\text { Calcium fluoride } 60 \\
\mathrm{mg} / \mathrm{g}(6.0 \% \mathrm{w} / \mathrm{w})\end{array}$ & $\begin{array}{l}\text { After shaking, thinly } \\
\text { paint tooth surfaces } \\
\text { to be treated. Special } \\
\text { foam pellet ("Pele } \\
\text { Tim") and suspension } \\
\text { is adsorbed within 10- } \\
20 \text { seconds and then } \\
\text { dried with air. }\end{array}$ & $\begin{array}{c}\text { Voco, } \\
\text { Germany }\end{array}$ \\
\hline $\begin{array}{c}\text { FGM } \\
\text { Desensibilize }\end{array}$ & $\begin{array}{c}10 \% \text { strontium } \\
\text { chloride } 5 \% \text { potassium } \\
\text { nitrate }\end{array}$ & \begin{tabular}{|c|} 
Apply to tooth, wait \\
for $10 \mathrm{~m}$, spread over \\
tooth with brush, \\
remove excess \\
material by either \\
water or cotton-swab.
\end{tabular} & Brasil \\
\hline $\begin{array}{l}\text { Clearfil } \\
\text { Esthetic } \\
\text { Cement }\end{array}$ & \begin{tabular}{|c|} 
Major components \\
within the primer; \\
HEMA, 10-MDP, 5- \\
NMSA, water, \\
accelerator. The main \\
components of resin \\
cement are Bis-GMA, \\
TEGDMA, hydrophobic \\
aromatic \\
dimethacrylate \\
monomers, silanated \\
barium glass \\
elephants. \\
\end{tabular} & $\begin{array}{c}\text { Apply primer to } \\
\text { surface, allow to dry } \\
\text { for } 30 \text { seconds and } \\
\text { then gently dry with } \\
\text { air after the excess is } \\
\text { removed with cotton } \\
\text { pellet. Then resin } \\
\text { cement is applied, } \\
\text { and each layer is light } \\
\text { polymerized. }\end{array}$ & $\begin{array}{c}\text { Kuraray, } \\
\text { Tokyo, } \\
\text { Japan) }\end{array}$ \\
\hline
\end{tabular}

Bis-GMA: bisphenol-A-diglycidyl methacrylate; HEMA: 2-hydroxyethy methacrylate; TEGDMA: Triethyleneglycol dimethacrylate; 10-MDP: 10-methacryloyloxydecyl dihydrogen phosphate; 5-NMSA, Nmethacryloyl-5-aminosalicylic acid.

\section{ESEM Analysis}

Following the application of the DA and the attachment of resin cement, one specimen was selected from each group and cut vertically into 2 parts and abraded with 600 and 1200 grit abrasive papers then the resin-dentin interfaces were analyzed (Fig. 1).

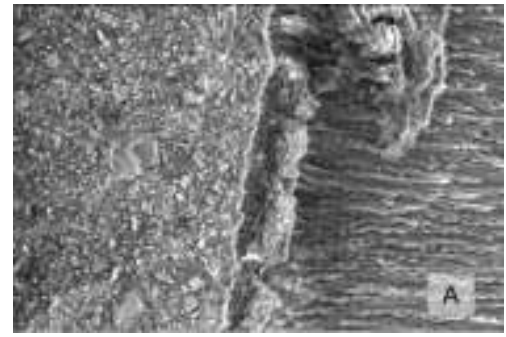

A. Control group; no desensitizer contamination, only resin cement.

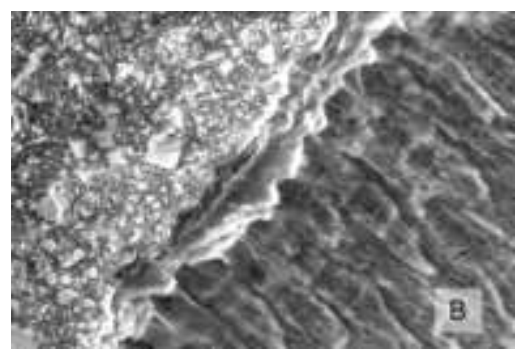

B. FGM group; Contamination of dentin with strontium chloride-potassium nitrate before resin cement.

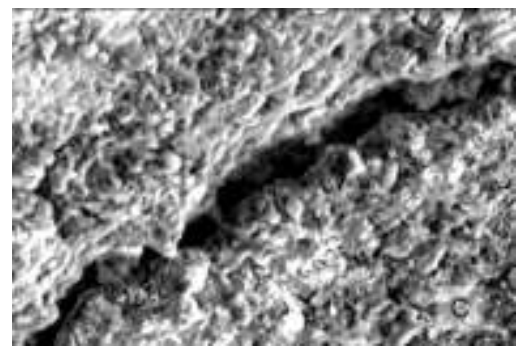

C. Bi-fluoride group; Contamination of dentin with fluoride before resin cement.

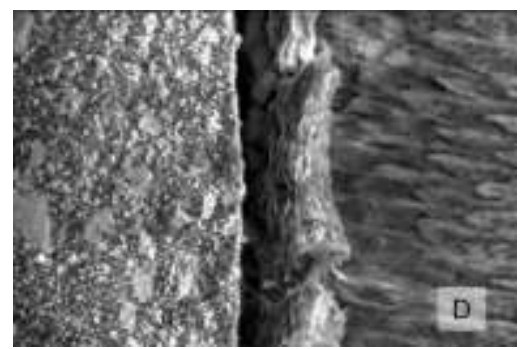

D. Gluma group; Contamination of dentin with Glutaraldehyde/HEMA before resin cement.

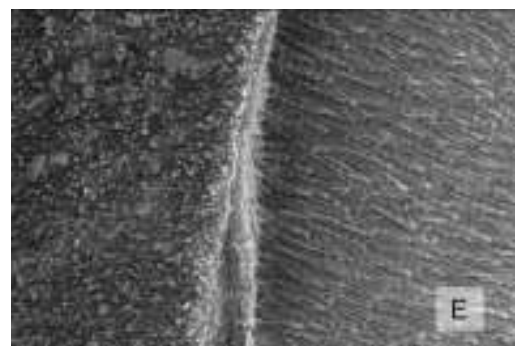

E. D-sense group; Contamination of dentin with calcium oxalate and potassium nitrate before resin cement. Figure 1. 
KUL, BAYINDIR,

İŞCAN YAPAR, YEŞİLDAL

\section{RESULTS}

The mean values of the microtensile bond strength (MPa) obtained with the post hoc Tamhane test are shown in Table 2. The statistical analysis revealed significant differences between the mean values of Gluma and the other desensitizing treatment groups and the control group regarding bond strength. The bond strength of the Gluma group was significantly lower than that of the other experimental and control groups $(p<0.05)$ The results for the Gluma, D-sense, Bi-fluoride, and Desensibilize experimental groups were similar to those of the control group $(p>$ F.05). Many of the specimens in which a desensitizer agent was applied had similar results to those of the specimens without any applied agent.

Table 2. Results of post hoc Tamhane test

\begin{tabular}{|c|c|c|c|c|c|c|}
\hline \multicolumn{7}{|c|}{$\begin{array}{c}\text { Dependent Variable: parameter } \\
\text { Tamhane }\end{array}$} \\
\hline \multirow[t]{2}{*}{ (I) grup } & \multirow[t]{2}{*}{ (J) grup } & \multirow{2}{*}{$\begin{array}{c}\text { Mean } \\
\text { Difference } \\
(I-J)\end{array}$} & \multirow[t]{2}{*}{\begin{tabular}{|l|} 
Std. \\
Error
\end{tabular}} & \multirow[t]{2}{*}{ Sig. } & \multicolumn{2}{|c|}{$\begin{array}{c}95 \% \text { Confidence } \\
\text { Interval }\end{array}$} \\
\hline & & & & & $\begin{array}{l}\text { Lower } \\
\text { Bound }\end{array}$ & $\begin{array}{l}\text { Upper } \\
\text { Bound }\end{array}$ \\
\hline \multirow{4}{*}{ control } & gluma & $2.63000^{*}$ & .83150 & .040 & .0784 & 5.1816 \\
\hline & bifluoroid & -.18000 & 1.02944 & 1.000 & -3.2419 & 2.8819 \\
\hline & \begin{tabular}{|l|}
$\mathrm{fgm}$ \\
\end{tabular} & -1.88000 & 1.09605 & .629 & -5.1370 & 1.3770 \\
\hline & dsense & -.24000 & 1.04108 & 1.000 & -3.3355 & 2.8555 \\
\hline \multirow{4}{*}{ Gluma } & control & $-2.63000^{*}$ & .83150 & .040 & -5.1816 & -.0784 \\
\hline & bifluoroid & $-2.81000^{*}$ & .74910 & .009 & -5.0960 & -.5240 \\
\hline & fgm & $-4.51000^{*}$ & .83829 & .000 & -7.0835 & -1.9365 \\
\hline & dsense & $-2.87000^{*}$ & .76502 & .009 & -5.2073 & -.5327 \\
\hline \multirow{4}{*}{ bifluoroid } & control & .18000 & 1.02944 & 1.000 & -2.8819 & 3.2419 \\
\hline & gluma & $2.81000^{*}$ & .74910 & .009 & .5240 & 5.0960 \\
\hline & $\mathrm{fgm}$ & -1.70000 & 1.03494 & .684 & -4.7787 & 1.3787 \\
\hline & dsense & -.06000 & \begin{tabular}{|l|}
.97653 \\
\end{tabular} & 1.000 & -2.9620 & 2.8420 \\
\hline \multirow{4}{*}{ fgm } & control & 1.88000 & 1.09605 & .629 & -1.3770 & 5.1370 \\
\hline & \begin{tabular}{|l|} 
gluma \\
\end{tabular} & $4.51000^{*}$ & .83829 & .000 & 1.9365 & 7.0835 \\
\hline & bifluoroid & 1.70000 & 1.03494 & .684 & -1.3787 & 4.7787 \\
\hline & dsense & 1.64000 & 1.04652 & \begin{tabular}{|l|}
.738 \\
\end{tabular} & -1.4720 & 4.7520 \\
\hline \multirow{4}{*}{ dsense } & control & .24000 & 1.04108 & 1.000 & -2.8555 & 3.3355 \\
\hline & \begin{tabular}{|l|} 
gluma \\
\end{tabular} & $2.87000^{*}$ & .76502 & .009 & .5327 & 5.2073 \\
\hline & bifluoroid & .06000 & .97653 & 1.000 & -2.8420 & 2.9620 \\
\hline & fgm & -1.64000 & 1.04652 & .738 & -4.7520 & 1.4720 \\
\hline
\end{tabular}

An SEM examination of the control group revealed that the tubules were generally open and that only some tubules were obstructed (Figure 1a). FGM (Figure 1b), Bi-fluoride (Figure 1c), and, D-sense (Figure 1e) were treated, and occlusion was clearly observed in some dentin tubules. Resin tags were detected in Gluma (Figure 1d), but this finding was not as consistent in the other groups. Furthermore, as the result of the smooth surface, no evidence of resin penetration was present. A similar microstructure to that shown in Figure 1e was demonstrated in Figure 1b. Because of the thickness of the bifluoride layer, it was not possible to identify some resin tags.

\section{DISCUSSION}

The application of desensitizers had no effect on the Mtbs, except for Gluma, which had a reduced mean Mtbs SEC to dentin than the other DAs and the control group. Therefore, the null hypothesis was partly supported.

In a study investigating the effects of DAs on dentin permeability, ${ }^{12}$ the agents were classified as those covering the tubules and those leading to the precipitation of proteins and crystals. The agents leading to the precipitation of crystals within the tubules reduced dentin permeability more than the others. While the fluoride-containing agents, used to treat extreme dentin hypersensitivity, precipitated sodium and calcium fluoride crystals dentin tubules, the agents containing resin provided long-lasting sensitivity relief through resin tag formation and the creation of a thin layer of polymerized resin surface covering the dentin tubules. ${ }^{4}$ The HEMA and glutaraldehyde contained in Gluma blocked the dentin tubules by coagulating the dentin fluid proteins. ${ }^{7}$ A limitation of in vitro studies is that the amount of dentin fluid protein in the tested extracted teeth is unknown.

The shear bond strength improved depending on glutaraldehyde/HEMA containing DA applied before the self-adhesive cement compared with the SEC luting process. ${ }^{7}$ Furthermore, in another study, ${ }^{14}$ shear bond strength increased after aging; this study also reported that Gluma influenced the bonding of selfadhesive resin cement (SAC) positively even when mastication was simulated. ${ }^{5}$ These results were not consistent with those of the current study where SEC was used instead of SAC. In the present study, pretreatment of the dentin surface with Gluma negatively influenced the Mtbs of the SEC to dentin. The bonding of the resin cement is substantially associated with the HEMA and glutaraldehyde concentration. ${ }^{6}$ Moreover, Qin et al. ${ }^{8}$ reported that the glutaraldehyde in Gluma was not able to cross-link mineralized dentin. Gluma has been reported to inhibit the bond strength of SEC as a result of the coagulation of proteins rather than the blocking of tubules. ${ }^{10,15}$ However, HEMA is hydrophilic and unstable ${ }^{25}$ and can affect the bonding strength after aging or water storage. ${ }^{14}$ In a study examining the 
effect of Gluma on dentin bonding after aging, better bonding was obtained with SAC compared with SEC. Therefore, the use of Gluma reduced the bond strength of self-etch resin cement. ${ }^{14}$ Additionally, Aranha et $\mathrm{al}^{25}$ reported that Gluma had no effect on bond strength values.

The bonding of conventional resin cement was reduced after Gluma application. ${ }^{15}$ Huh et $\mathrm{al}^{10}$ reported that after Gluma application, the use of selfetching primer negatively affected resin cement bonding. In the current study, the bond strength of the Gluma-treated specimens was reduced compared with that of the controls. This reduction may be related to the use of different adhesives, resin cement types, and primers, methods of surface roughening with acid, and bonding strength tests. Gluma contains HEMA, which may rehydrate the collagen matrix after air-drying. The lower $\mathrm{Mtbs}^{26}$ result for this desensitizer agent when compared with that of other agents is difficult to explain. Sealing of the dentinal tubules by the precipitates and also the funnel-shaped tubules as demonstrated by Arrais et $\mathrm{al}^{2}$ may be factors.

Calcium oxalate crystals form as a result of the reaction of the ionized calcium present in the dentinal tubules with potassium oxalate. According to Acar et $\mathrm{al}^{1}{ }^{1}$ the oxalate desensitizer reduced the Mtbs of SAC to dentin. These crystals cover the dentinal surface, including the tubule orifice; thus, the adhesive resins cannot bond adequately to the oxalate-applied dentin. ${ }^{17,20}$ Pashley et $\mathrm{al}^{21}$ reported that treating etched dentin with potassium oxalate gel created crystals within the tubules, leading to reduced crystal formation on the surface. They also reported that the development of crystals within the tubules did not prevent the development of a hybrid layer. Like the current study, Tay et $\mathrm{al}^{2}{ }^{24}$, reported that Mtbs values were similar to those of the nontreated dentin when oxalates were used. According to Shafiei et $\mathrm{al}^{11}$ oxalate had no effect on bonding in the etch and rinse resin cement system. Studies using all kinds of DA using recently introduced SECs are lacking. ${ }^{1}$

The application of a desensitizer with oxalate has been reported not to affect the bonding between resin cement (Panavia F2.0, SEC) and dentin. ${ }^{10} \mathrm{~A}$ low $\mathrm{pH}$ value oxalate application replaces the smear layer with calcium oxide crystals. ${ }^{9,10}$ According to the SEM images, open tubules were detected with oxalate particles that had entered the tubules, enabling the development of resin tags. ${ }^{10}$ Kolker et al, $^{12}$ reported that some of the tubules appeared to be closed. D- sense crystal precipitate was found adjacent to the tubular walls, and the tubules apparently extended toward the dentin surface. Although the tubules were obstructed as a result of the development of insoluble crystals on the peritubular dentin, the reason some tubules were open may be related to the development of a hybrid layer. ${ }^{11}$

This study was not able to fully replicate the clinical performance of desensitizing agents with resin cement. However, without direct evidence regarding the way that desensitizers react with resin cement, clinicians should avoid their use before cementing indirect restorations. Other limitations of the study include the limited number of DAs tested. Additionally, DAs were applied according to the manufacturer's recommendations, and it may be that thickness can also affect bond strength. Comparing different types of adhesive resin cements in future studies is recommended. Additionally, the evaluation of different situations such as fatigue or aging treatments may affect the outcomes.

\section{CONCLUSIONS}

Considering the limitations of this study, using D-Sense, Desensibilize, and Bi-fluoride on dentin can be recommended if used together with a self-etch resin cement when required. Additionally, pretreating dentin with D-Sense, Desensibilize, and Bi-fluoride had no negative effect. However, Gluma may negatively affect bonding with SEC.

NOT: Calışmada herhangi bir yazar, kurum ya da kuruluş ile çıkar çatışması içerisinde bulunmamaktadır. Makale daha önce hiçbir yerde yayınlanmamış ve yayınlanmak üzere işlem görmemektedir

\section{REFERENCES}

1. Acar O, Tuncer D, Yuzugullu B, Celik C. The effect of dentin desensitizers and Nd:YAG laser pretreatment on microtensile bond strength of selfadhesive resin cement to dentin. J Adv Prosthodont 2014; 6:88-95

2. Arrais CA, Chan DC, Giannini M. Effects of desensitizing agents on dentinal tubule occlusion. J Appl Oral Sci 2004; 12:144-8.

3. Soeno K, Taira Y, Matsumura H, Atsuta M. Effect of desensitizers on bond strength of adhesive luting agents to dentin. J Oral Rehabil 2001; 28:1122-8. 
KUL, BAYINDIR,

İŞCAN YAPAR, YEŞİLDAL

4. Pereira JC, Martineli AC, Tung MS. Replica of human dentin treated with different desensitizing agents: a methodological SEM study in vitro. Braz Dent J 2002; 13:75-85.

5. Stawarczyk B, Hartmann L, Hartmann R, et al. Impact of Gluma Desensitizer on the tensile strength of zirconia crowns bonded to dentin: an in vitro study. Clin Oral Investig 2012; 16:201-13.

6. Munksgaard EC, Asmussen E. Bond strength between dentin and restorative resins mediated by mixtures of HEMA and glutaraldehyde. J Dent Res 1984; 63:1087-9.

7. Sailer I, Oendra AE, Stawarczyk B, Hämmerle $\mathrm{CH}$. The effects of desensitizing resin, resin sealing, and provisional cement on the bond strength of dentin luted with self-adhesive and conventional resincements. J Prosthet Dent 2012; 107:252-260.

8. Qin C, Xu J, Zhang Y. Spectroscopic investigation of the function of aqueous 2-hydroxyethylmethacrylate/glutaraldehyde solution as a dentin desensitizer. Eur J Oral Sci 2006; 114:354-9.

9. Pashley $\mathrm{DH}$. Clinical considerations of microleakage. J Endod 1990; 16:70-7.

10. Huh JB, Kim JH, Chung MK, Lee HY, Choi YG, Shim JS. The effect of several dentin desensitizers on shear bond strength of adhesive resin luting cement using self-etching primer. J Dent 2008; 36:1025-32.

11. Shafiei F MM, Alavi AA, Namvar B. The effect of oxalate desensitizers on the micro leakage of resin composite restorations bonded by etch and rinse adhesive system. Oper Dent 2010; 35:682-8.

12. Kolker JL, Vargas MA, Armstrong SR, Dawson DV. Effect of desensitizing agents on dentin permeability and dentin tubule occlusion. J Adhes Dent 2002; 4:211-21.

13. Cortiano FM, Rached RN, Mazur RF, Vieira S, Freire A, de Souza EM. Effect of desensitizing agents on the microtensile bond strength of twostep etch-and-rinse adhesives to dentin. Eur J Oral Sci 2016; 124:309-15.

14. Stawarczyk B, Hartmann R, Hartmann L, Ross M, Özcan M, Sailer I, et al. The effect of dentin desensitizer on shear bond strength of conventional and self-adhesive resin luting cements after aging. Oper Dent 2011; 36:492-501.

15. Yim NH, Rueggeberg FA, Caughman WF, Gardner FM, Pashley DH. Effect of dentin desensitizers and cementing agents on retention of full crowns using standardized crown preparations. J Prosthet Dent 2000; 83:459-65.

16. Sailer I, Tettamanti S, Stawarczyk B, Fischer J, Hämmerle $\mathrm{CH}$. In vitro study of the influence of dentin desensitizing and sealing on the shear bond strength of two universal resin cements. J Adhes Dent 2010; 12:381-392.

17. Pashley EL, Tao L, Pashley DH. Effects of oxalate on dentin bonding. Am J Dent 1993; 6:116-118.

18. Orchardson R, Gillam DG. Managing dentin hypersensitivity. J Am Dent Assoc 2006; 137:9908.

19. Pereira JC, Segala AD, Gillam DG. Effect of desensitizing agents on the hydraulic conductance of human dentin subjected to different surface pre-treatments an in vitro study. Dent Mater 2005; 21:129-38.

20. De Andrade e Silva SM, Malacarne-Zanon J, Carvalho RM, et al. Effect of oxalate desensitizer on the durability of resin-bonded interfaces. Oper Dent 2010; 35:610-7.

21. Pashley DH, Carvalho RM, Pereira JC, Villanueva R, Tay FR. The use of oxalate to reduce dentin permeability under adhesive restorations. Am J Dent 2001; 14:89-94.

22. Tay FR, Frankenberger R, Krejci I, et al. Singlebottle adhesives behave as permeable membranes after polymerization. I. In vivo evidence. J Dent 2004; 32:611-21.

23. Vachiramon $\mathrm{V}$, Vargas $\mathrm{MA}$, Pashley $\mathrm{DH}$, et al. Effects of oxalate on dentin bond after 3-month simulated pulpal pressure. J Dent 2008;36:178-85.

24. Tay FR, Pashley DH, Mak YF, Carvalho RM, Lai SC, Suh BI. Integrating oxalate desensitizers with total-etch two-step adhesive. J Dent Res 2003; 82:703-7.

25. Aranha AC, Siqueira Junior AeS, Cavalcante LM, Pimenta LA, Marchi GM. Microtensile bond strengths of composite to dentin treated with desensitizer products. J Adhes Dent 2006; 8:85-90.

26. Tekçe N, Demirci M. Mikrogerilim bağlanma dayanım testi ve sonuçlarını etkileyen etkenler. J Dent Fac Atatürk Uni 2014; 24:134-52

\section{Yazışma Adresi}

Dr. Öğr. Üyesi Ruhi YEŞİLDAL

Department of Mechanical Engineering, Faculty of Engineering at Atatürk University, Erzurum, TURKEY

e-mail: esra.kul@atauni.edu.tr 